\title{
Patterns of seasonal phytoplankton dynamics as the element of ecological successional changes proceeding in a lake (Lake Kortowskie, northern Poland)
}

\author{
Bożena Jaworska $^{1^{*}}$, Bogusław Zdanowski ${ }^{2}$ \\ ${ }^{1}$ University of Warmia and Mazury, Department of Applied Ecology, Oczapowskiego 5, 10-957 Olsztyn, Poland; \\ e-mail: bozena.jaworska@uwm.edu.pl \\ ${ }^{2}$ Institute of Inland Fisheries, Department of Hydrobiology, Oczapowskiego 10, 10-719 Olsztyn, Poland; \\ e-mail: bzdanowski@infish.com.pl
}

\begin{abstract}
The aim of the research was to determine the successional changes proceeding in the phytoplankton of a lake. The basis of the study was the analysis of long-term seasonal changes in the taxonomic structure and the estimation of the intensity of algal community development in phytoplankton of Lake Kortowskie. Seasonal changes in the phytoplankton taxonomic structure manifested themselves as a decreasing share of Bacillariophyceae in spring and autumn and Chlorophyta in summer phytoplankton. The retreating chlorophytes and the diatoms were replaced by blue-green algae,the increasing share of which caused a reduction in the stability of the remaining phytoplankton taxonomic groups, and consequently, taxonomic shifts and progressive development of the overall phytoplankton community in all phenological seasons. Intensive algal growth was observed in spring and lasted until late autumn. The highest phytoplankton biomass was always recorded in summer. Summer phytoplankton development was related to increased bluegreen algae domination, the massive growth of which was observed from spring to autumn. The development of the Cyanoprokaryota community had a negative impact on the diatoms, since the latter earlier disappeared from the biocenosis in spring and re-developed to a lesser degree in autumn.
\end{abstract}

Key words: lake, phytoplankton, domination structure, biomass, ecological succession

\section{Introduction}

Particular trophic lake types exhibit specific seasonal phytoplankton taxonomic composition, which results in the similarity of the qualitative and quantitative phytoplankton structure in successive years (Sommer et al. 1986; Gawler et al.1988; Lair and Ayadi 1989; Wirtz and Eckhardt 1996). However each occurrence of ecological stress of a particular direction and intensity may lead to the sequence of harmonic variations in the lake that can result in shifts in the biocenosis of phytoplankton. Some species representing characteristic groups may occur for more than one year or dominate in other periods than is suggested by the general pattern of seasonal succession. Some algal species may undergo adaptation to disturbances caused by ecological stress. Nevertheless, the general structure of the phytoplankton community and its succession is to some degree stable and recurrent but depends on the range of ambient factors related to the ecosystem (Lin 1972; Munawar et al. 1988; Reynolds 1988; Talling 1993; Tallberg et al. 1999; Anneville et al. 2002). The modification of factors, whose combined acting determines the maintenance of the ecological equilibrium, may stimulate the acceleration of the rate of ecological succession in lake. Persistent changes may even lead to a final change in the trophic status of a lake as ecological succession appears not only within the limits of a particular trophic stage but can also determine the lake's conversion from one trophic state to another (Burchardt 1993; Burchardt et al. 1994; Burchardt and Łastowski 1999; Reynolds 2000; Reynolds et al. 2002).

The aim of this study was to analyse long-term seasonal changes in the domination structure and the intensity of the algal community development in phytoplankton of Lake Kortowskie as a basis for the deter- 
mination of ecological successional changes proceeding in phytoplankton.

\section{Study area}

The studies were conducted on Lake Kortowskie. It is located in the northeastern part of Poland, in the Mazurian Lakeland, within the limits of the town of Olsztyn. The lake has an elongated shape along the axis north-south. The reservoir is composed of three distinct parts: the south basin (S) of a maximal depth of $17.2 \mathrm{~m}$, the north basin of a maximal depth of 15.7 $\mathrm{m}$ and the middle part that is relatively shallow, of a maximal depth of $6 \mathrm{~m}$, which separates the two basins. The lake's surface area is $940,000 \mathrm{~m}^{2}$ and its volume is $5,323,000 \mathrm{~m}^{3}$ with a water table of $103.3 \mathrm{~m}$ above sea level (Synowiec 1965). The total drainage basin of the lake is $38.0 \mathrm{~km}^{2}$. The direct drainage basin of the lake is $1,020,000 \mathrm{~m}^{2}$. The lake is supplied by 5 inflows. There is only one river outflow - the Kortówka River - a tributary of the Łyna River, which is located in the southeastern part of the reservoir. The amount of water flowing out of the lake is regulated by a weir that enables the removal of hypolimnion water by a pipeline installed in the southern part of the lake (Lake Kortowskie has been restored by the method of removal of nutrient-rich hypolimnion water to impede progressing eutrophication of the reservoir). The northern part of the lake is separated from the southern one (by shallows of a depth of $6 \mathrm{~m}$ ) and is not directly influenced by pipeline activity similarly to the water layer from 0 to $6 \mathrm{~m}$ depth in the entire lake.

\section{Methods}

Studies of phytoplankton were carried out at two sites located in two local basins: in the southern ( $\mathrm{S}$ site) and northern ( $\mathrm{N}$ site) part of the lake in the water layer from 0 to $5 \mathrm{~m}$ depth. Phytoplankton analyses began in 1987, during spring mixing, and were finished in 1991 during winter water stagnation; the next studies lasted from spring 1999 to winter 2000. The frequency of sampling depended on the season. Samples were taken three times during summer periods, and two times in spring, autumn and winter periods. Preliminary qualitative phytoplankton analysis was conducted on living organisms collected with a plankton net. Fundamental qualitative and quantitative plankton analyses were carried out based on fixed samples obtained from a water column $0-5 \mathrm{~m}$ (smaller than the depth of the layer that separates the two basins) and concentrated by the settling method. Qualitative analysis was performed according to Starmach (1989) using the drop method to calculate the number of individuals. Phytoplankton biomass was calculated based on cell volume measurements (Heusden 1972; Starmach 1989). Qualitative and quantitative phytoplankton analyses were performed using the following microscope magnifications: $1.25 \times 10 \times 40$ or $1.25 \times 10 \times 100$.

Statistical characteristics of results included minimal values (min.), maximal values (max.), mean values ( $\mathrm{x}$ ) and standard deviation (SD). Normality was assessed with the Shapiro-Wilks test. The significance of differences in mean phytoplankton biomass recorded at particular sites and phenological seasons were tested using the Mann-Whitney test or Kruskal-Wallis test. The similarity of algal associations in the successive phenological seasons was measured by a hierarchical classification of cluster analysis.

\section{Results}

Phytoplankton in Lake Kortowskie showed relatively similar seasonal dynamics at the studied sites ( $>0.001$, during the whole period of the study). In general, phytoplankton of Lake Kortowskie showed highly significant diversity of total biomass in particular seasons (spring seasons: $\mathrm{H}=32.6$; $\mathrm{p}<0.001$; summer seasons: $\mathrm{H}=88.4 ; \mathrm{p}<0.001$; autumn seasons: $\mathrm{H}=$ 84.5; $\mathrm{p}<0.001$; winter seasons: $\mathrm{H}=79.1 ; \mathrm{p}<0.001)$.

In spring biomass ranged from $5.5 \mathrm{mg} \mathrm{dm}^{-3}$ to $17.2 \mathrm{mg} \mathrm{dm}^{-3}$, while the mean values from $9.3 \mathrm{mg}$ $\mathrm{dm}^{-3}(\mathrm{SD} \pm 1.5)$ to $11.1 \mathrm{mg} \mathrm{dm}{ }^{-3}(\mathrm{SD} \pm 3.9)$ in 1987 1991. In spring 1999 algal biovolume reached a maximum of $21.7 \mathrm{mg} \mathrm{dm}^{-3}$ and the mean value rose to $16.7 \mathrm{mg} \mathrm{dm}^{-3}(\mathrm{SD} \pm 4.2)$. Bacillariophyceae were the group that dominated in the spring season. However, their maximal biomass was gradually declining from 12.0 to $5.7 \mathrm{mg} \mathrm{dm}^{-3}$ in the years $1987-1990$, and consequently, their contribution to the total algal biomass decreased from 71.2 to $60.6 \%$. In the year 1999/2000, the share of Bacillariophyceae in the total algal biovolume dropped to $45.6 \%$. It is noteworthy that in that year, the dominant species typical of the spring season like Asterionella formosa Hass. and Stephanodiscus rotula (Kütz.) Hend., were replaced by Cyanoprokaryota earlier. The biomass of Chlorophyta in the spring season did not exceed $2.8 \mathrm{mg} \mathrm{dm}^{-3}$. A drop was recorded in the share of that algal group from 16.5 to $12.5 \%$ in 
the years 1987-1990 and even to $8.7 \%$ in 1999 , whereas Cyanoprokaryota biomass was successively increasing from 1.4 to $2.7 \mathrm{mg} \mathrm{dm}^{-3}$ in 1987-1990 and reached 8.9 $\mathrm{mg} \mathrm{dm}^{-3}$ in 1999. During that period of time, that algal group constituted, respectively, $10-25 \%$ and $41 \%$ of the total phytoplankton biomass (Fig. 1, Fig. 5).

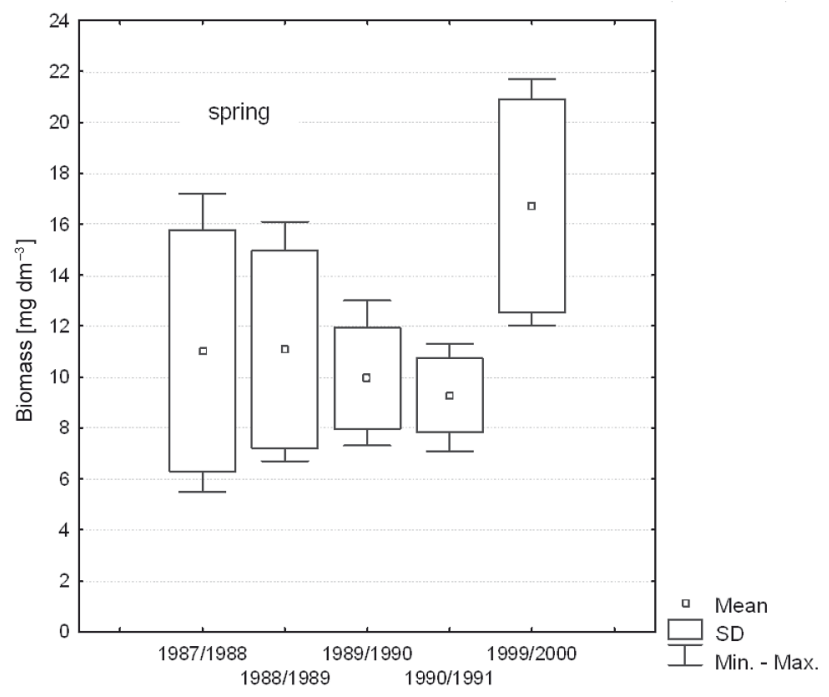

Fig. 1. Dynamics of spring phytoplankton biomass in the epilimnion of Lake Kortowskie in the years 1987-1991 and 1999-2000

In summer in the years 1987-1990 phytoplankton biovolume varied in narrow limits, on average, from $12.0 \mathrm{mg} \mathrm{dm}^{-3}$ (SD \pm 2.9 ) to $12.8 \mathrm{mg} \mathrm{dm}^{-3}$ (SD $\pm 1.7)$ and did not exceed $18.1 \mathrm{mg} \mathrm{dm}^{-3}$. In the limnological year 1999/2000, the growth was observed of the mean summer biovolume up to $28.8 \mathrm{mg} \mathrm{dm}^{-3}$ (SD \pm 5.3 ), while the maximal recorded value achieved 36.7 $\mathrm{mg} \mathrm{dm}{ }^{-3}$. The species that developed in early summer were representatives of Chlorophyta: Pandorina morum (O.F. Müll.) Bory or Eudorina elegans Ehr. and Pediastrum sp. During summer peaks, growth was recorded of Cyanoprokaryota: Microcystis aeruginosa (Kütz.) Kütz., Anabaena spiroides Kleb., and later also Anabaena flos-aqae (L.) Ralfs. The contribution of Chlorophyta to the total biomass decreased from 44.4 to $23.7 \%$, while the share of blue-green algae in the community increased from 40.4 to $47.7 \%$ in the years 1987-1991. Distinct domination of Cyanoprokaryota was recorded in summer 1999. Then, Aphanizomenon flos-aqae (L.)Ralfs prevailed with co-dominance of filamentous blue-green algae. Cyanoprokaryota constituted about $73.3 \%$ of the total phytoplankton biomass. The share of Chlorophyta dropped to $14.7 \%$ and of Bacillariophyceae to $4.6 \%$ (Fig. 2, Fig. 5).

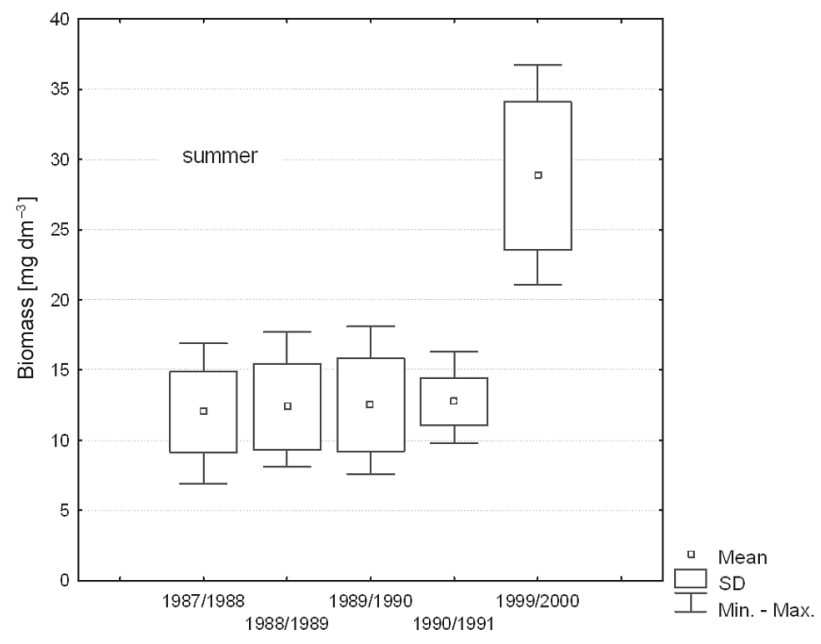

Fig. 2. Dynamics of summer phytoplankton biomass in the epilimnion of Lake Kortowskie in the years 1987-1991 and 1999-2000

In autumn, phytoplankton biomass in the first three years of the study reached, on average, $5.6 \mathrm{mg}$ $\mathrm{dm}^{-3}(\mathrm{SD} \pm 1.6)$. It increased to $8.6 \mathrm{mg} \mathrm{dm}^{-3}(\mathrm{SD} \pm 1.2)$ in the limnological year 1990/1991, and reached 18.2 $\mathrm{mg} \mathrm{dm}^{-3}$ (SD \pm 3.1 ) in the year 1999/2000. In that season of the year the biovolume was mainly formed by Bacillariophyceae. The dominant species were the diatoms Asterionella formosa Hass. and Aulacosiera islandia (O. Müll.) Sim. However, the share of those algae gradually decreased from 72 to $56 \%$ in the years 1987 1991 and to $21 \%$ in $1999 / 2000$. At the time, the proportion of Cyanoprokaryota in the total phytoplankton biomass reached 68\% (Fig. 3, Fig. 5).

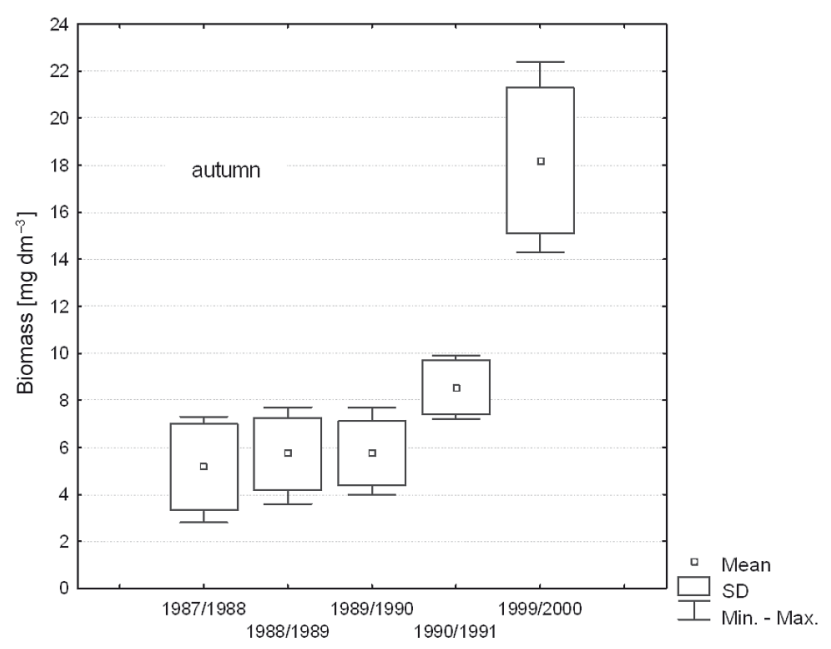

Fig. 3. Dynamics of autumn phytoplankton biomass in the epilimnion of Lake Kortowskie in the years 1987-1991 and 1999-2000 
Winter phytoplankton biomass was relatively low (>5 $\mathrm{mg} \mathrm{dm}^{-3}$ ). During that season, the share of Bacillariophyceae in the total algal biovolume decreased from 75.3 to $56.6 \%$, whereas the proportion of Cyanoprokaryota increased from 8.5 to $36.9 \%$. The biomass of the latter algal group depended on the growth of Limnthorix planctonica (Wolosz.) Meff., Limnothrix redeckei (Van Goor) Meff. and Planktothrix agardhii (Gom.) as well as other filamentous bluegreen algae and was supported by the relatively low proportion of Pediastrum (Fig. 4, Fig. 5).

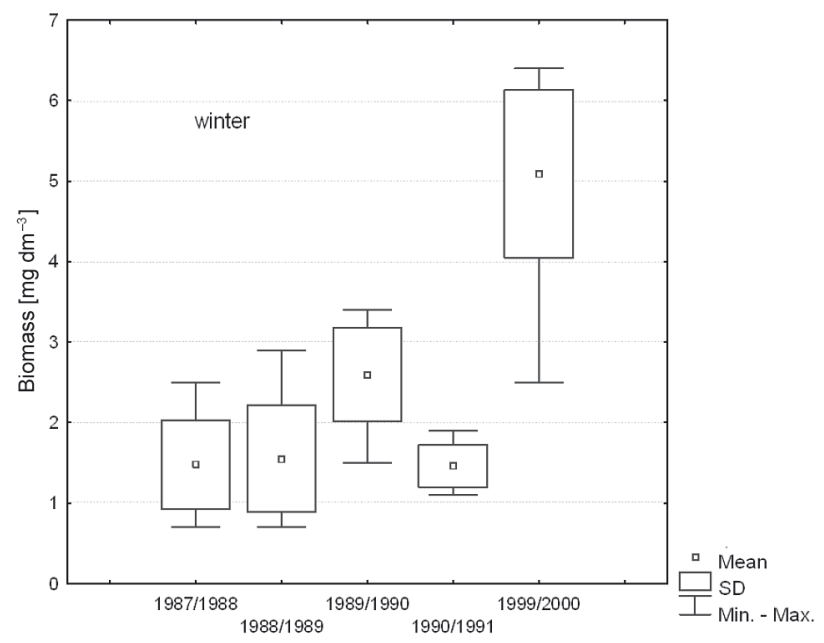

Fig. 4. Dynamics of winter phytoplankton biomass in the epilimnion of Lake Kortowskie in the years 1987-1991 and 1999-2000
It was recorded that the quantitative structure of phytoplankton which developed in spring and autumn in the years 1987-1991 demonstrated high similarity. A high rate of similarity was also recorded in the case of the winter communities during the entire period of the study, whereas summer plankton underwent gradual structural changes, which resulted in increasing dissimilarity of the community in subsequent years. A particularly distinct phytoplankton quantitative structure was recorded in summer 1999. Also spring and autumn communities in that year were not similar to those observed in the respective seasons in the preceding years (Fig. 6).

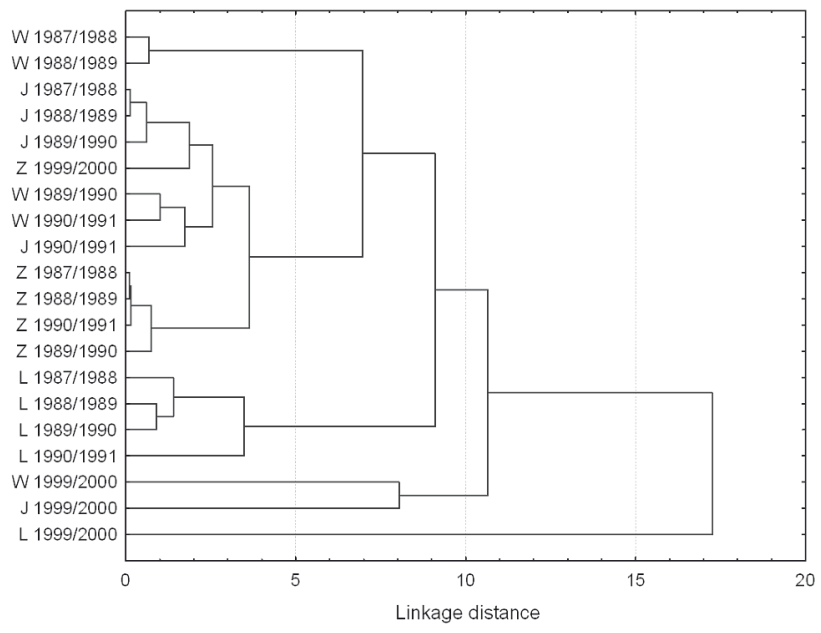

Fig. 6. Similarity of quantitative structure of phytoplankton in Lake Kortowskie in the phenological seasons of the years 19871991 and 1999-2000 (W - spring, L - summer, J - autumn, Z winter)

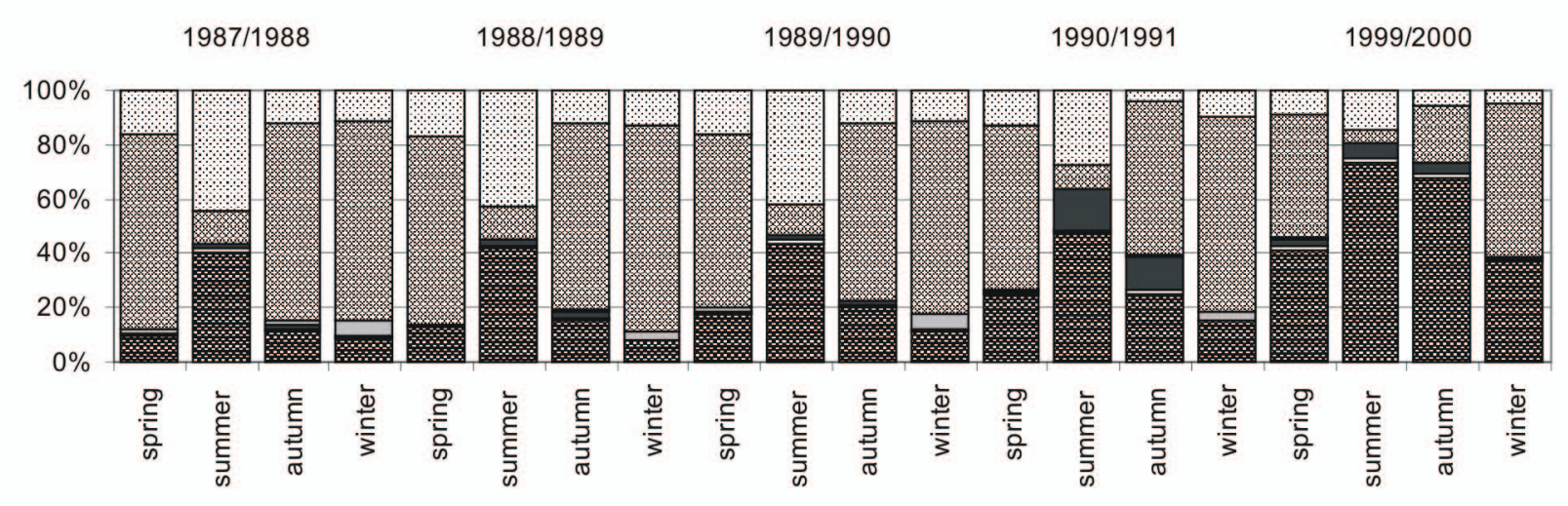

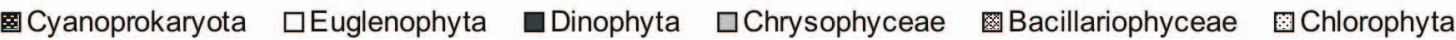

Fig. 5. Share of particular systematic groups in the biomass of phytoplankton in Lake Kortowskie in the years 1987-1991 and 1999-2000 


\section{Discussion}

Phytoplankton succession in eutrophic, temporal lakes exhibit a specific pattern regarding taxonomic structure and biomass: a spring peak of small-size phytoplankton species and summer domination of large-size organisms resistant to consumers pressure. Both peaks are separated by a winter minimum that is determined by limited light conditions and by early summer inhibition of algae growth, called the clear water phase (Sommer et al. 1986; Gawler et al.1988; Lair and Ayadi 1989; Wirtz and Eckhardt 1996). Recurrence of the succession pattern in subsequent limnological years depended on ambient physical factors, nutrient concentrations and biotic interactions (Munawar et al. 1988; Reynolds 1988, 2000; Talling 1993; Tallberg et al. 1999; Anneville et al. 2002; Reynolds et al.2002). Annual phytoplankton seasonal succession in Lake Kortowskie followed a recurrent pattern consistent with that typical of eutrophic lakes of the temperate zone, though slightly modified. The timing of phytoplankton development during the year underwent some changes. The development of spring phytoplankton biocenosis is to a great extent determined by abiotic factors, and in spring, plankton succession always has an allogenic character. The structure and dynamics of phytoplankton are influenced by water mixing in a reservoir, intensity of light radiation, and increasing water temperature, resources of silica and availability of nutrients $(\mathrm{N}, \mathrm{P})$ activated during spring mixing. According to Tuji (2000), the light intensity and the length of the day have a decisive impact on the successional strategy of phytoplankton in spring. Krivtsov et al. (2000) claim that silica plays an important role then, while Talling (1993) stresses that the intensity of phytoplankton development during this season mainly depends on phosphorus and nitrogen resources. Bleiker and Schanz (1989) proved that spring turnover regulate all processes acting during this process. In Lake Kortowskie, high availability of nutrients and increased light conditions in spring stimulated fast growth of species representing Bacillariophyceae, among which dominated: Asterionella formosa Hass., Fragilaria crotonensis Kitt. and Fragilaria capucina Des., and also, in the final period of this study, Aulacoseira granulata (Ehr.) Sim., Aulacoseira islandica (O.Müll.) Sim. and Stephanodiscus rotula (Kütz.) Hend. In the successive years of the period 1987-1990, the spring peak of phytoplankton development became gradually lower and finally, in 1990/1991 the intensity of phytoplankton growth was higher in summer than in spring. This tendency was also observed in 1999/2000. The decline in the growth of diatoms, which manifests itself as their increased sedimentation, often takes place after a sudden increase in water temperature and the onset of summer stratification (Talling 1993; Tuji 2000). This usually coincides with silica-depletion (Krivtsov et al. 2000), more seldom with nitrogen or phosphorus depletion, and is often accompanied by unsteady relations between the development of phytoplankton and the abundance or structure of zooplankton. The decrease in the plankton growth rate in spring may be deepened by algal death due to zooplankton grazing (Elser et al. 1987) as well as by expansion of species better adapted for varying environment conditions (Giraudet et al. 1997). According to Burgi et al. (1999), variations in phytoplankton biomass caused by intensive zooplankton grazing in late May and early June and algae redevelopment after that period may depend on the trophic state of the reservoir. It is often observed that herbivorous zooplankton become food-limited due to the growth of non-edible forms of algae. If herbivorous forms (mainly large-bodied Cladocera) are not numerous and the grazing upon phytoplankton is limited, diatoms are usually replaced by blue-green algae which are better adapted for unfavourable environment conditions (Shapiro 1990). In Lake Kortowskie, increased water temperature in spring and subsequent early onset of summer stratification limited the occurrence of diatoms but, on the other hand, favoured blue-green algae growth. The range of tolerance to temperature and related tolerance to light radiation and energy demand mean that blue-green algae can successfully compete with other phytoplankton groups (Dauta et al. 1990). Moreover, when in the biocenosis, algae vulnerable to sedimentation, like diatoms, are replaced by taxa capable of vertical migration in the water body, i.e. blue-green algae with gas vacuoles, the cells' sedimentation rate becomes significantly limited and, consequently, the turnover of nutrients in the epilimnion is considerably longer (Klemer et al. 1982; Lafforgue 1995). The ability to regulate buoyancy is an important feature that allows bluegreen algae to be suspended in the trophogenic layer as well as to occupy the most favourable depth (Ganf and Oliver 1982; Humphries and Lyne 1988). Colonization of a particular water layer is related to limited vertical mixing and thermal stratification, light range as well as composition and abundance of the phyto- 
plankton community. Furthermore, progressing food limitation and increasing importance of competition mechanisms shaping the structure of the phytoplankton community are observed. In eutrophic lakes, in summer, zooplankton may suffer from strong food limitation as during this season phytoplankton is often composed of non-edible forms. As a consequence, a large proportion of primary production cannot be utilized by herbivorous organisms. Due to low vulnerability to grazing (Elser et al. 1987; Kurmayer and Jutter 1999; Hambright et al. 2001), blue-green algae may be an important source of organic carbon in the environment supporting the functioning of the detrital loop. Such a trophic pattern is typical of a highly eutrophic environment (Currie 1990; Del Giorgio and Peters 1994; Carpenter et al. 1997) and probably occurred in Lake Kortowskie, where intensive bluegreen algae development was already observed in spring and lasted until late autumn with the peak in late August and early September. The shift in the timing of the phytoplankton peak from summer to late summer may indicate high nutrient availability in the reservoir and late autumn mixing, which was confirmed by the results of the studies of physico-chemical water properties of Lake Kortowskie (Dunalska 2002; Mientki and Dunalska 2001; Wiśniewski and Mientki 2002). High stability of summer thermal stratification supports autogenic succession of phytoplankton. Succession mechanisms are based on the activity of organisms that modifies the environment in a way which is unfavourable for them, which, in turn, may lead to a decrease in their competitive ability. These organisms can be replaced by other taxa, better adapted for newly established environment conditions. In Lake Kortowskie, the species typical of the spring season were Chlorophyta: a predominance of Pandorina morum (O.F. Müll.) Bory, and at the end of the study also Phacotus lenticularis (Her.) Stein., species of the Pediastrum genus, Pediastrum boryanum (Tur.) Men. in particular, which were always co-dominating taxa, and sometimes Coelastrum microporum Näg. A.Braun. The aforementioned early summer species underwent increasing selection (Ganf and Oliver 1982), contrary to blue-green algae species whose fast reaction to changing environment conditions and efficient mechanisms responsible for adaptation probably favoured their growth and enhanced their domination in the biocenosis (Keating 1977; Pick and Lean 1987; Lathrop 1988; Shapiro 1990; Brooks et al. 1999). The species that dominated were Microcystis aerugi- nosa (Kütz.) Kütz. and Anabaena spiroides Kleb. or Anabaena flos-aqae (Lyng.) Breb., which at the beginning prevailed periodically, but later their massive development was permanent, especially the following species: Aphanizomenon flos-aqae (L.)Ralfs. Woronichinia naegeliana (Unger) Elen., Limnothrix planctonica (Wolosz.) Meff. and Limnothrix redeckei (VanGoor) Meff. The blue-green algae mentioned above were constant components of the summer plankton community, whose occurrence was prolonged until early autumn. The duration of their development became from year to year successively longer and finally in 1999/2000 blue-green algae prevailed in the reservoir as early as in May and stayed in the position of dominance until October. The diatoms replacing the bluegreen algae in autumn had year after year a shorter time to reach the peak during this season. As a consequence, the autumnal breakdown of summer species' dominance was weaker in subsequent years. The impact of a set of environmental factors also supported the dominance of blue-green algae (Mientki and Dunalska 2001; Dunalska 2002; Wiśniewski and Mientki 2002). The pace of successional shifts also depended on hydrological factors (Mientki and Teodorowicz 1996). Progressing changes in the hydrological balance of Lake Kortowskie could affect the taxonomic structure and the intensity of phytoplankton development (Dunalska et al. 2001). The hydrological regime that manifests itself by increased retention of epilimnion waters and reduced water level in the lake during summer may deepen the stagnation of epilimnion waters in warmer summer months, increase the accumulation of nutrients in this water layer and enhance the development of the algae typical of stagnant waters. Warmer spring and summer seasons, the occurrence of windless periods, and lack of ice cover, might also intensify shifts in taxonomic structure and phytoplankton growth rate affecting the pace of successional changes in the epilimnion of Lake Kortowskie.

\section{Conclusion}

Long-term studies on seasonal changes of phytoplankton revealed that (in spite of the natural ability of the phytoplankton community to resist interannual variations as well as rapid changes within the annual cycle) there were shifts in algal taxonomic structure and progressing phytoplankton development in the epilimnion of Lake Kortowskie. The community of 
blue-green algae limited the development and stability of other plankton groups, determined the earlier regression of diatoms in spring and their weaker development in autumn, and also succeeded in competition with the remaining phytoplankton taxa in summer. This process was identified as ecological successional changes, the pace of which was gradually increasing.

\section{References}

Anneville O., Ginot V., Druat J.C., Angeli N., 2002, Longterm study (1974-1998) of seasonal changes in the phytoplankton in Lake Geneva: a multi-table approach, J. Plank. Res. 24(10): 993-1008.

Bleiker W., Schanz F., 1989, Influence of environmental factors on the phytoplankton spring blooms in Lake $\mathrm{Zu}$ rich, Aquat. Sci. 51(1): 47-58.

Brooks J., Ganf D., Green D., Whittington J., 1999, The influence of light and nutrients on buoyancy, filament aggregation and flotation of Anabaena circinalis, J. Plank. Res. 21: 327-341.

Burchardt L., 1993, Bioindication in the assessment of lake ecosystem, [in:] Burchardt L. (eds), Theory and practices in ecosystems research, Idee Ekol. 3(2): 39-44.

Burchardt L., Łastowski K., 1999, The problem of using common species in bioindication: Basis term, Acta Hydrobiol. 41(3/4): 231-234.

Burchardt L., Łastowski K., Szmajda P., 1994, Różnorodność ekologiczna a bioindykacja (Ecological diversity and bioindication), [in:] Burchardt L. (eds), Teoria i praktyka badań ekologicznych (Theory and practices in ecosystems research), Idee Ekol., 4(3): 27-44. (in Polish).

Burgi H., Heller C., Gaebel S., Mookerji N., Wand J., 1999, Strength of coupling between phyto and zooplankton in Lake Lucerne (Switzerland) during phosphorus abatement subsequent to a weak eutrophication, J. Plank. Res. 21: 485-507.

Carpenter S.R., Cole J.J., Kitchell J., Pace M., 1997, Impact of dissolved organic carbon, phosphorus and grazing on phytoplankton biomass and production in experimental lakes, Limnol. Oceanogr. 43(1): 73-80.

Currie D.J., 1990, Large-scale variability and interactions among phytoplankton, bacterioplankton and phosphorus, Limnol. Oceanogr. 35(7): 1437-1455.

Dauta A., Devaux J., Piquemal F., Boumnich L., 1990, Growth rate of four freshwater algae in relation to light and temperature, Hydrobiologia 207: 201-226.

Del Giorgio P.A., Peters R.H., 1994, Patterns in planktonic P:R ratios in lakes: Influence of lake trophy and dissolved organic carbon, Limnol. Oceanogr. 39(4): 772-787.

Dunalska J., 2002, Influence of limited water flow in a pipeline on the nutrients budget in a lake restored by hypolimnetic withdrawal method, Pol. J. Environ. Stud. 11(6): 631-637.
Dunalska J., Wiśniewski G., Mientki C., 2001, Water balance as factor determining the Lake Kortowskie restoration, Limnol. Rev. 1: 65-72.

Elser J., Goff J. C., Mackay N.A., St-Amand A.L., Elser M.M., Carpenter S.R., 1987, Species specific algal responses to zooplankton: experimental and field observations in three nutrient limited lakes, J. Plank. Res. 9(4): 699-717.

Ganf G.G., Oliver R.L., 1982, Vertical separation of light and available nutrients as a factor causing replacement of green algae by blue-green algae in the plankton of a stratified lake, J. Ecol. 70: 829-844.

Gawler M., Balvay G., Blanc P., Druart J.P., Pelletier J.P., 1988, Plankton ecology of Lake Geneva. A test of the PEG-model, Arch. Hydrobiol. 114(2): 161-174.

Giraudet H., Berthon J.L., Buisson B., 1997, A comparison of the daily alkaline phosphatase activity of a cyanobacterium (Microcystis aeruginosa) and a diatom (Synedra capitata), Biochem. 320: 451-458.

Hambright K.D., Zohary T., Easton J., Azoulay B., Fishbein T., 2001, Effects of zooplankton grazing and nutrients on the bloom-forming, $\mathrm{N}_{2}$-fixing cyanobacterium Aphanizomenon in Lake Kinneret, J. Plank. Res. 23(2): 165-174.

Heusden G.P.H., 1972, Estimation of the biomass of plankton, Hydrobiologia 39(2): 165-208.

Humphries S.E., Lyne V.D., 1988, Cyanophyta blooms: the role of cell buoyancy, Limnol. Oceanogr. 33(1): 79-91.

Keating K.I., 1977, Allelopathic influence on blue green bloom sequences in a eutrophic lake, Science 196: 885-887.

Klemer A.R., Feuillade J., Feuillade M., 1982, Cyano-bacterial blooms: carbon and nitrogen limitation have opposite effects on the buoyancy of Oscillatoria, Science 215: 1629-1631.

Krivtsov V., Bellinger E.G., Sigee D.C., 2000, Changes in the elemental composition of Asterionella formosa during the diatom spring bloom, J. Plank Res. 22(1): 169-184.

Kurmayer R., Jutter F., 1999, Strategies for the co-existence of zooplankton with the toxic cyanobacterium Planktothrix rubescens in Lake Zurich, J. Plank. Res. 21: 659683.

Lafforgue M., Szeligiewicz W., Devaux J., Poulin M., 1995, Selective mechanisms controlling algal succession in Aydat Lake, Wat. Sci. Tech. 4: 117-127.

Lair N., Ayadi H., 1989, The seasonal succession of planktonic events in lake Aydat, France. A comparison with the P. E. G. model, Arch. Hydrobiol. 115(4): 589-602.

Lathrop R.C., 1988, Evaluation of whole-lake nitrogen fertilization for controlling blue-green algal blooms in a hypereutrophic lake, Can. J. Fish. Aquat. Sci. 45: 2061-1075.

Lin C., 1972, Phytoplankton succession in eutrophic lake with special reference to blue-green algal blooms, Hydrobiologia 39(3): 321-334.

Mientki C., Dunalska J., 2001, Phosphorus balance at various water flow in a lake restored by hypolimnetic withdrawal, Ecohydrol. Hydrobiol. 1(4): 417-422.

Mientki C., Teodorowicz M., 1996, Assessment of the effects of hypolimnion water removal from the Kortowskie Lake, Chem. Prot. Environ. 2: 362-374. 
Munawar M., Munawar I., McCarthy E., 1988, Seasonal succession of phytoplankton size assemblages and its ecological implications in the North American Great Lakes, Verh. Internat. Verein. Limnol. 23: 659-671.

Pick F.R., Lean D.R.S., 1987, The role of macronutrients (C, $\mathrm{N}, \mathrm{P}$ ) in controlling cyanobacterial dominance in temperature lakes, New Zeal. J. Mar. Fresh. Res. 21: 425-434.

Reynolds C.S., 1988, The concept of ecological succession applied to seasonal periodicity of freshwater phytoplankton, Verh. Internat. Verein. Limnol. 23: 638-691.

Reynolds C.S., 2000, Phytoplankton designer- or how to predict compositional responses to trophic-state change, Hydrobiologia 424: 123-132.

Reynolds C.S., Huszar V., Kruk C., Naselli-Flores L., Melo S., 2002, Towards a functional classification of the freshwater phytoplankton, J. Plank. Res. 24(5): 417-428.

Shapiro J., 1990, Current beliefs regarding dominance by blue-greens: The case for the importance of $\mathrm{CO}_{2}$ and pH, Verh. Internat. Verein. Limnol. 24: 38-54.

Sommer U., Gliwicz Z.M., Lampert W., Duncan A., 1986, The PEG-model of seasonal succession of planktonic events in freshwaters, Arch. Hydrobiol. 106: 433-471.

Starmach K., 1989, Plankton roślinny wód słodkich. Metody badania i klucze do oznaczania gatunków występujących w wodach Europy Środkowej (Freshwater phytoplankton. Study methods, key to freshwater species of Central Europe), PWN, Warszawa-Kraków, p. 496. (in Polish).
Synowiec A., 1965, Morfologia Jeziora Kortowskiego (Morphology of Lake Kortowskie), Zesz. Nauk. WSR Olszt. 19: 3-16 (in Polish).

Tallberg P., Horppila J., Vaisanen A., Nurminen L., 1999, Seasonal succession of phytoplankton and zooplankton a trophic gradient in a eutrophic lake - implication for food web management, Hydrobiologia 412: 81-94.

Talling J. F., 1993, Comparative seasonal changes, and inter-annual variability and stability, in a 26-year record of total phytoplankton biomass in four English lake basins, Hydrobiologia 268: 65-98.

Tuji A., 2000, The effect of irradiance on the growth of different forms of freshwater diatoms: implications for succession in attached diatom communities, J. Phycol. 36: 659-661.

Wirtz K.-W., Eckhardt B., 1996, Effective variables in ecosystem models with an application to phytoplankton succession, Ecol. Model. 92(1): 33-53.

Wiśniewski G., Mientki C., 2002, The influence of changes in the catchment basin on the quantity of biogene loads brought into restored Lake Kortowskie, Limnol. Rev. 2: 433-441. 